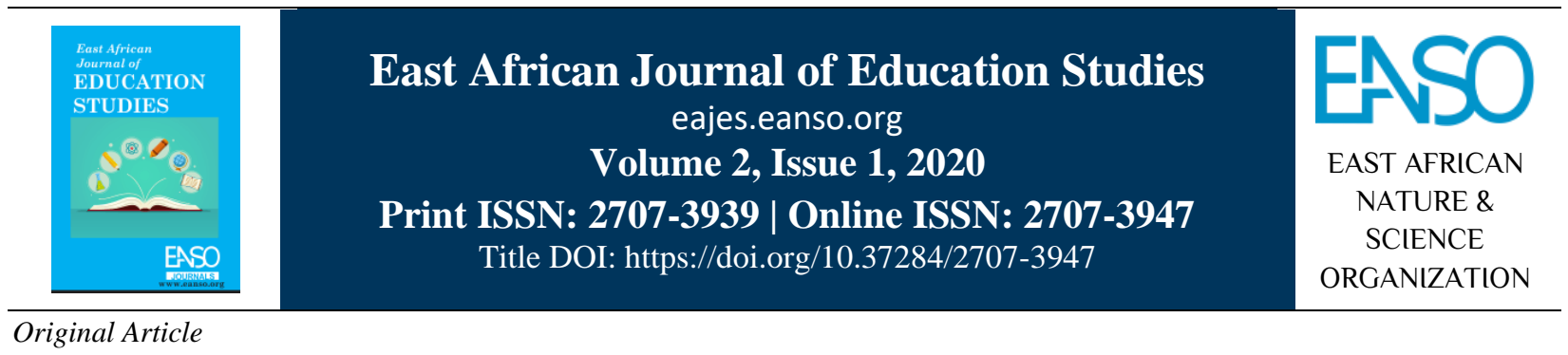

\title{
The Dynamics of Art and Craft Curriculum in Enhancing Child Growth and Development
}

\author{
Wanyama Ogutu $^{1 *}$ \\ ${ }^{1}$ Department of Fine Art and Design, Kenyatta University, Nairobi, Kenya. \\ *Correspondence email: wanyamaogutu93@gmail.com
}

Article DOI: https://doi.org/10.37284/eajes.2.1.134

\author{
Article history: \\ Received: 12 Mar 2020 \\ Accepted: 02 Apr 2020 \\ Published: 08 Apr 2020 \\ Keywords:

Art and Craft,
Child Growth,
Task Force Review,
Education Stakeholder,
Kenya Vision 2030. \\ Art and Craft, \\ Task Force Review, \\ Kenya Vision 2030.
}

\begin{abstract}
As the government of Kenya is geared towards achieving sustainable development goals and Kenya Big 4 Agenda, the Ministry of Education rolled out the new education system 2-6-3-3-3 dubbed "Competence Base Curriculum" whose mission is to nurture every learner's potential. It received overwhelming appraisal from different stakeholders;- locally and internationally eliciting debates in the local media, radio and television talk shows. Prior to this bold step in the curriculum, the government of Kenya set up various taskforces to review the 8.4.4 curricula in 1992, 1995, 2002, 2009 and 2011, reviewed by the late Professor Douglas Odhiambo which asserted the atrocities of children not developing to their full potential and its negative effect in threatening the realization of Kenya Vision 2030. The paper has established diverse ways in which the curriculum in art and craft is enhancing the growth and development of a child's emotional, physical, cognitive, and creativity. It has hypothetical employ qualitative analysis to examine art and craft in terms of the art stages of growth and development of a child. Further, the paper has briefly observed that naturalistic child growth and development of Leonardo Da Vinci - (A high renaissance artist of $14^{\text {th }}$ century)- and the researcher's teaching experience, as the case study and scope. It has concluded that any curriculum design ought to consider art and craft because it has an inherent psychological and development power that develops a child into full potential.
\end{abstract}

\section{APA CITATION}

Ogutu, W. (2020). The Dynamics of Art and Craft Curriculum in Enhancing Child Growth and Development. East African Journal of Education Studies, 2(1), 18-24. https://doi.org/10.37284/eajes.2.1.134. 


\section{CHICAGO CITATION}

Ogutu, Wanyama. 2020. "The Dynamics of Art and Craft Curriculum in Enhancing Child Growth and Development". East African Journal of Education Studies 2 (1), 18-24. https://doi.org/10.37284/eajes.2.1.134.

HARVARD CITATION

Ogutu, W. (2020) "The Dynamics of Art and Craft Curriculum in Enhancing Child Growth and Development", East African Journal of Education Studies, 2(1), pp. 18-24. doi: 10.37284/eajes.2.1.134.

\section{IEEE CITATION}

P. Alabu, J. Kembo, and A. Otara, "Influence of Principals' Conflict Management Techniques on Teacher Job Satisfaction in Selected Secondary Schools in Uriri and Nyatike Sub Counties, Kenya”, EAJES, vol. 2, no. 1, pp. 8-17, Mar. 2020.

\section{MLA CITATION}

Ogutu, W. "The Dynamics of Art and Craft Curriculum in Enhancing Child Growth and Development". East African Journal of Education Studies, Vol. 2, no. 1, Apr. 2020, pp. 18-24, doi:10.37284/eajes.2.1.134.

\section{INTRODUCTION}

The National Institute for Health Research (NIHS) asserts the broad spectrum of sports, music, and arts to effectively enhance the growth and development of children, according to Lacey and Luff (2007). The biological test was carried at the children's hospital in Harvard Pediatric Health Service in Boston, United States. Lacey \& Luff (2007) explicitly explained how art and craftworks as a catalyst in the growth and development of a child physically, emotionally, creative, socially, and cognitively. They established that activities such as painting, drawing, clay modelling, and paperwork are indeed a vessel for healing in psychological impairment for children with cerebral palsy, autism, Down syndrome, and dyslexia. For instance, Ruppert (2006) noted that the Federal Government, through the U.S Department of Education instituted art \& craft as a mandatory subject for all public and private schools. He noted that the U.S Department of Education Research team had found out that art and craft subjects gave children opportunities and experiences which were not found on other disciplines of learning. The Curriculum designs on the Competence-Based Curriculum CBC (2017) show that Art \& Craft strands are linked to other subject areas such as mathematics, religion, and environment among others. On the other hand, it was found that Art \& Craft stands on its own as entrepreneur subject and art therapy healing for distress, trauma, and stress. Ruppert (2006) shows empirical studies have shown that states such as California, Texas, and Columbia in the United States of America use art \& craft as a means of sharpening intelligence in children.
The government of Kenya is on the journey to achieve sustainable development goals as was layout in the vision 2030; - so that it can be rank as other $1^{\text {st }}$ world states like Japan and the United States. (Republic of Kenya 2007). The previous government of retired President Kibaki came up with the millennium development goal that saw free primary education and schools built in rural areas among others. The current government under the presidency of Uhuru Kenyatta is spearheading the Big 4 Agenda; - manufacturing been one of the goals. The other goals include universal health care, food security, and affordable housing is supposed to help in attaining, three pillars that are in shrined on the vision 2030 among them been investing in people of Kenya.

In the effort to answer the Kenyatta University Biennial Research and innovation conferences 2019 subtheme: - 'Transformative, Inclusive and Equitable quality education'. The researcher noted that the president of the Republic of Kenya delivered free secondary education by recruiting more teachers among others. It is also noted that the country is in a new education system reform dubbed by the competency-based curriculum. Prior to developing Competency-Based Curriculum (CBC), the task force reviews of 2009, 2011, Njuguna, Kamau, and Owino's (2008) report and Namwamba (2005) and several Kenya Educational seasonal papers (2015), - asserted that precious curriculum did not allow children to develop into their full potential. The task force reviews and Kenya seasonal educational papers also noted the danger that downplayed the power of Art \& Craft when it was scrapped from the precious 884 system. Kimari (2002), and Njuguna, Kamau and Owino's. 
(2008) reports have attached it to some of the atrocious that the country faced a high rate of employment among the youth. This is threatening the realization of vision 2030 as far as investing in Kenya is concerned.

This paper came up as a result of Kenyatta University Biennial Research and Innovation conference 2019 with the intention to fulfil the theme on the achievement of sustainable development and Kenya's Big Four Agenda, where it tends to established different ways in which of art and craft curriculum can enhance the growth and development of the child

\section{LITERATURE REVIEW}

\section{Theoretical on Growth and Development}

The growth and development of the child emotionally physically and cognitively have been the subject of analysis by psychologists and philosophers for a long time. Its results provide guidance to other areas of studies according to Shaffer and Kip (2007). They defined that growth and development are continuous systematic continue change that occurs in every organism, plant to human beings. Shaffer and Kip (2007) noted that growth and development in human beings occur through biological and psychological systematic change. They outlined different development stages starting from the conceptual period; infancy toddle- childhood, adolescence, youth, adulthood, old age and end with death. Sroufe, Duggal, Weinfield, and Carlson (2000) explained that psychological inherent and biological changes and environmental adaptation are factors that effects growth and development.

Stewart and Koch (1983) explained that before the development of the theory, children were regard and treated as mature. They explained that philosopher John Locker critically imposed an opposition view and stated that children grow and develop in stages based on emotion, cognition, and creativeness. Shaffer and Kip (2007) noted that John Locker described a child as being born with a blank mind referred to as "tabula rasa." Stewart and Koch (1983) noted that philosopher Jean Jacque Rousses supported John Locker on children disregarding them being as a mature adult. Rousses further explained that children are born with psyche that allows them to explore the world. They both concluded that Rousses and Locke agreed by stating to explore the creativity of a child, they should be left on their own without human interference.

Berk (1989) and Shaffer and Kip (2007) explained that Sigmund Freud, a psychoanalyst argued that the growth and development of children based on basic instinct and spontaneous reaction that entailed sexuality and aggressiveness. They outlined three stages of Freud as Id- (an instant response to satisfy the need that more font with baby); Ego- (a rational response that is accompanied with child personality) and Super Ego- (a more rational development). Bukatka and Daehle (1995) noted contradiction on Erikson who thought Sigmund psychosexual was limited but stated that the development of the child is triggered by a social crisis that involves instinct and spontaneous reaction. They outlined the Erik Erickson crisis stage as basic trust verse mistrust for age 1-3; autonomy verse shame for age 3-6; initiative verse guilty for age 6-9; and industry verses inferiority for 6-12.

Berk (1989) noted agreement between John Watson and John locker that children's development is not based on psychological and emotional or inborn instinct, as stated by Sigmund and Erickson, but dependent on the environment in which a child is brought up. Bukatka and Daehle (1995) stated Albert Bandura observed that children tend to be influenced by observing the influential member of society as "a model" on what they do and involved in. Bandura noted that children's brain is active processors of information whose responds to new and varieties of impulses including influential people of society or community and influences of the environment and surround most through observation.

According to Berk (1989), Jean Piaget views that the development of children is cognitive, where a child manipulates and translates ideas, concepts, and experience at a certain age of life as they grow and develop at the different stages. She outlines Piaget's cognitive development as a sensor motor birth for age 2 (thinking is limited to sensory impression); - pre-operation for age 2-5 (use the 
mental image in arts to represent their world); concrete operations for age 6-11 (they think in the abstract can translate idea well. Stewart and Koch (1983) noted Lev Vygotsky viewed the development of a child been influenced by cultural traditions that are acquired through the cooperation of knowledge with a member of authority in the society who tends to possess high knowledge.

\section{Art \& Craft and Child growth and development}

Art and craft was a term used by lower primary and kindergarten schools in Kenya according to Education System (1985). The system was initiated by late President Moi with the vision of "Education for citizen self-reliance" making art and craft one of the subjects that would drive the realization of the 8.4.4. Vision. "Marketing Crafts and Visual Arts", defined the term "art \& craft" as modules in visual arts such as painting, sculpture, and photography, which uses or manipulates elements/ materials to express feeling or perception of the world, hence, judged by sight. The 8.4.4 Education system (1985) categorized art and craft subjects as follows; drawing, painting, modelling, clay work, papercraft and weaving. The education system, 26-3-3-3 Competence-Based Curriculum CBC (2017) have added a few subjects such as pattern making, fabric decoration, painting, and colouring. Moreover, different visual art scholars and art educationist over the world have structured the art $\&$ craft to suit their education curriculum system.

Lark-Horovitz (1967) noted that art and craft is an instrument for a child to gain a great understanding of their personality, emotions, and environment. Ruppert (2006) stated that art and craft are vital subjects for a well-rounded personality. Schirmacher (2002) noted that psychologists have even asserted that art and craft in children tremendously help in penetrating the mind of children and helps in growth and development. Moreover, psychiatrists have realized that art and craft for children are useful in clinical diagnosis and healing therapy, according to Lark-Horovitz (1967). According to Schirmacher (2002), thinking skills like imagination, intuition, creative thinking, reasoning, and problem-solving are well expressed in art \& craft. The CBC curriculum considers art \& craft as an important area of study that will champion attainment of the core competence embedded within the education reforms.

\section{Childhood on Leonardo Da Vinci}

Koestle (2006) explained the biography of Leonardo Da Vinci based on his child's growth and development as follows; that he was an Italian high renaissance artist of the $14^{\text {th }}$ century born in Florence. At age 3, Leonardo had already developed physically, emotionally, creatively, socially, and cognitively. The father discovered his child's artistic talent and linked him to an apprentice who developed his artist skills both on art knowledge and skills with different art media. He developed socially when he spent most of his time in the garden helping his grandfather. He loved the outdoor exhibition, exploration of flowers, meadows, climbing hillside and relaxing under the shadow. He developed cognition as he liked to draw and study of animals and birds such as lizard, horse, oxen and cow. In the sketchbook, Leonardo noted his memories and wrote poems of great ancient philosophers with handwriting, which refined his fine motor skills that enabled him to paint masterpiece paintings such as "Mona Lisa," "The last supper," and several explicit sketches. The early creative experience of Leonardo in art and craft enabled him to invent first aeroplanes and military tankers.

\section{The Newly Competency-Based Curriculum}

The Competency-Based of Curriculum is designed with the mission of 'Nurturing every learner's potential' according to education system 2-6-3-3-3 (2017). It will identify the potential of every child and nurture the potentials through learning pathways. Thus, fulfilling its vision of "A Kenyan citizen who is engaged, empowered and ethical". The core competencies that guide the learning areas such as Literacy Activities;- Kiswahili language Activities;- Kenya sign language;- English language activities;- mathematical;environmental;- hygiene and nutrition;- religion;movement and creative activities and pastoral programmer of Instruction are communication and collaboration;- self-efficacy;- critical thinking and problem-solving;- creativity and imagination;learning to learn;- digital literacy and citizenship. The art and craft fall under the creative activities 
learning area. In the new $\mathrm{CBC}$ curriculum, art and craft fall on the broad are creative arts which comprise of art and craft itself, music and psychomotor that emphasis on enthusiasm and motivation.

\section{RESEARCH METHODOLOGY}

The research employed a descriptive research design to qualitatively analyze the diverse way to which art and craft enhance child growth and development. A naturalistic observation was used to examine phenomenal change on pupil $\mathrm{X}$ as primary data when subjected to art and craft activities. The population was a lower primary school at Embakasi Nairobi- Kenya, where a director $\mathrm{K}$ of the school approached the researcher about starting an art program. It was due to roll up of CBC curriculum that demands that all school switches to the new education system. The target population was children age 3-5 from middle-level people living in Embakasi, Tasia, Pipeline and Baraka estate in Nairobi. Non-probability convenient sampling was used to sample pupil $\mathrm{X}$ because of much involvement in art craft activities and good support from his class teacher and parent. The researcher used unstructured participation to observe phenomenal naturalist changes in pupil X. The checklist was structured to assess how pupil $\mathrm{X}$ reacted to art and craft physically emotionally, socially, cognitively, and creatively. The researcher obtained the consent authority from the school administration, parents, and teacher to conduct the study. The researcher up-held professionalism in conducting the research in fairness, not infringing on the rights, lifestyle, and habits of school, pupil X parent, and teacher.

\section{HYPOTHETICAL RESEARCH FINDINGS AND DISCUSSION}

\section{Table 1: Summary of Development of Pupil X}

\begin{tabular}{|c|c|c|c|c|}
\hline Physically & Emotional & Socially & Cognitive & Creativity \\
\hline $\begin{array}{l}* \text { Create art in clay, } \\
\text { painting \& } \\
\text { papercraft. }\end{array}$ & $\begin{array}{l}\text { *Excited about art class. } \\
\text { *Communicated love, } \\
\text { care, and hope. }\end{array}$ & $\begin{array}{l}\text { *Communicated } \\
\text { love, care, and hope. } \\
\text { *Collaborated with } \\
\text { other pupils. }\end{array}$ & $\begin{array}{l}\text { *Create art in clay, } \\
\text { painting \& papercraft. } \\
\text { *Dedicate art to her } \\
\text { mother. } \\
\text { *Improve in academics. } \\
\text { * her mother been subject } \\
\text { matter. }\end{array}$ & $\begin{array}{l}* \text { Create art in clay, } \\
\text { papercraft. } \\
* \text { her mother been } \\
\text { subject matter. }\end{array}$ \\
\hline
\end{tabular}

The Art and craft strand in $\mathrm{CBC}$ in curriculum designs on art craft such as clay work, painting, and paperwork, according to Pupil $\mathrm{X}$ to refine of fine motor, perceptual and sensory skills According to Schirmacher (2002) it the exercise in clay work and painting improve muscle relaxation. This helps in food digestion and adequate rest after the activities, according to CBC (2017) curriculum. It promotes the value of handwork and relates to other activities like writing.

The activities in art and craft such as pattern making are done in groups with the involvement of teacher, parent, or guardian. The activities develop pupil X with good social skills in a working environment. The pupil X was able to learn from others during the art and craft activities which were exciting that made Pupil $\mathrm{X}$ express his own emotions, temperament, and personality. This helps to develop core competence of Communication and collaboration skills in-group as pupils exchange their ideas. Pupil $\mathrm{X}$ became responsible and respectful to the class teacher and parents.

In art and craft, papercraft involves discovering and working with paper. It gives children an opportunity to freely express themselves and experience joy, pride, and self-discovery. During card design session pupil X created a beautiful card dedicating to his mother. The art and craft activities helped to develop a positive mental attitude towards life. Imagination and creativity skills on pupil $\mathrm{X}$ provide room for allowing a fantasy dream to be expressed, which results in the healing process, according to Schirmacher (2002).

Other activity areas are in drawing and painting. They assist in developing cognitive of a child in 
different stages based on Jean Piaget's theory. This gives children the opportunity for mental stimulation, curiosity, and exploration. They are then eager to learn for themselves and from the world according to Schirmacher (2002). During art and craft sessions, pupil $\mathrm{X}$ had a chance to display, talk about, and appreciate their own and others' work that was dedicated to the dear mother. According to CBC (2017), art and craft activities ought to equip a child's cognitive ability to translate ideas, concepts, and experiences that were evident to pupil $\mathrm{X}$. These attributes improved the efficacy of thinking skills like problem-solving, reasoning, and imagination.

All the strands on the CBC curriculum design on Art \& Craft activities are creative oriented. The strands give children an opportunity to develop an expression of their own creative uniqueness on the activities. Core Competencies that pupil $\mathrm{X}$ acquired during art sessions were imagination and creativity skills. Pupil X expressed these competencies through innovation \& creativity in creating imaginative concepts on various forms of art and craft. The activities enable pupil $\mathrm{X}$ to be self-aware of ability and develop high self-esteem creative work. This was evident in exploration, experimentation, and invention through verbal and non- verbal communication when creating all pieces of art and dedicating to the mother.

\section{CONCLUSION AND RECOMMENDATIONS}

Any school curriculum design ought to develop the full potential of the child, socially, physically, emotionally cognitive and creative. It can be well foster by the art and craft due to inherent power psychological development. Art and craft has the basic attribute of competence in imaginative, critical and creative thinking. This enables a child to solve problems that they faced and confront time to time. The theories on various psychologists have art and craft activities such as drawing and painting playing a vital role in child development and growth. Pupil $\mathrm{X}$ is one among many children in our society who when given the opportunity to express themselves in art craft activities would develop self-efficacy. Art and craft activities should not be regarded as time and resources wasting learning area, but vital for helping children discovers the full potential.
Noting the diverse discussion on the dynamic of art and craft as a vessel for developing children in full potential, the researcher outlined the following recommendation.

The curriculum developers and stakeholders who are mandated to develop and design Art and Craft subjects in the school curriculum ought to base their designing on the psychological development of the child. This will avoid hindering the child from developing freely as they enjoy and explore the world. This has been well articulated in the development theory by Jean Jacque Rouses, among others. They need for partnership, collaboration, and grants to develop a full research study so that the hypothetical findings can be asserted in its effect on the growth and development of the child. It will imply that different research methodology is employed in the study. The study dynamic of art and craft curriculum, enhancing child growth and development, can work well if continuous study because growth and development is a syngeneic change that occurs in the period of time, so they is need to conduct these studies.

\section{REFERENCES}

Berk, R. J. (1989). Differential aspects of psychoanalysis of the aged: Discussion. Psychoanalysis \& Psychotherapy, 7(1), 44-48.

Bukatko, D. \&Daehler, M. W. (1995). Child Development: A thematic approach. Boston: Houghton Mifflin Company.

Competence-Based Curriculum. (2017). Curriculum Design for PP1, PP2. Grade 3, 4. Nairobi: Kenya Institute of Curriculum Development.

Education System - 2-6-3-3-3. (2017). Basic Education Framework Curriculum; Competence Base Curriculum. Nairobi: Kenya Institute of Curriculum Development.

Education system 8-4-4 (1985) Education for Selfreliance. Nairobi: Kenya Institute of Education (KIE). 
Kimalu, P. K. (2002). A situational analysis of poverty in Kenya (No. 6). Kenya Institute for Public Policy Research and Analysis.

Koestle, A. R. (2006). Leonardo Da Vanci; Artist, Inventor \& Renaissance Man. Philadelphia Chelsea House.

Lacey, A., \& Luff, D. (2007). National Institute for Health Research: Qualitative Data Analysis. Yorkshire \& the Humber

Lark-Horovitz, B. (1967). Understanding children's art for better teaching. C. E. Merrill Books

Namwamba, T. D. (2005). Essentials of Critical \& Creative Thinking Introduction to Creative and Critical Thinking. Nairobi: Didaxis Publishers

Njuguna, N., Kamau, T., \& Owino, O. (2008). Unlocking the future potential for Kenya: The Vision 2030. Preliminary draft chapter 4. Nairobi: Government printer.

Republic of Kenya. (2007). Government of Kenya, Vision 2030. Nairobi: Government Press

Ruppert, N. (2002). Critical Evidence: How the Arts Benefit Student Achievement.Washington, DC: AEP.

Schirmacher, R. (2002). Art and creative development for young children (4th Edition). Albany, NY: Delmar Thomson Learning

Shaffer, D. R., \& Kip, K., (2007) Development of Psychological Childhood and Adolescence. John Wiley \& Sons.

Sroufe, L. A., Duggal, S., Weinfield, N., \& Carlson, E. (2000). Relationships, development, and psychopathology. In Sameroff, A. J., Lewis, M. \& Miller, S. M. (Eds), Handbook of developmental psychopathology (pp. 75-91). Boston, MA: Springer.

Stewart, A. C., \& Koch, J. B. (1983). Children Development through Adolescence. Canada: John Wiley \& Sons. 